\title{
Fabrication of Heterojunctions Based on Chemically Deposited Copper Oxide Thin Films for Solar Cell Application
}

\author{
Muhammad Muhibbullah and Masaya Ichimura \\ Department of Engineering Physics, Electronics and Mechanics, \\ Nagoya Institute of Technology, Gokiso-cho, Showa-ku, Nagoya 466- 8555, Japan \\ Fax:+81-052-735-5581, e-mail: mmuhibbullah@yahoo.com, ichimura.masaya@nitech.ac.jp
}

To fabricate the heterojunction, copper oxide $\left(\mathrm{Cu}_{2} \mathrm{O}\right)$ layers were deposited by the chemical bath deposition technique using aqueous solutions containing $\mathrm{CuSO}_{4}$ and $\mathrm{Na}_{2} \mathrm{SO}_{3}$ without and with adding a small amount of ethylendiamine (EDA). The counterpart of the heterojunction, i.e., a $\mathrm{ZnO}$ layer was deposited by electrochemical deposition. Indium-tin-oxide (ITO) coated glass sheet was used as a substrate, and both the substrate $\left(\mathrm{ZnO} / \mathrm{Cu}_{2} \mathrm{O} / \mathrm{ITO}\right)$ and superstrate $\left(\mathrm{Cu}_{2} \mathrm{O} / \mathrm{ZnO} / \mathrm{ITO}\right)$ structures were fabricated. The $\mathrm{Cu}_{2} \mathrm{O}$ films were crystalline with a cubic crystal structure, had $\mathrm{Cu} / \mathrm{O}$ ratios of 1.7 - 2, and consisted of octahedral particles, whose size was reduced by addition of EDA. The $\mathrm{Cu}_{2} \mathrm{O}$ layers exhibited p-type conductivity and phtosensitivity. Rectification properties and week photovoltaic effects were observed for the heterojunctions fabricated using the solution with EDA.

Key words: copper oxide, heterojunction, chemical bath deposition, solar cell.

\section{INTRODUCTION}

Copper oxide is advantageous for the photovoltaic application since its band gap, absorption coefficient and photosensitive properties are suitable for solar cells. Furthermore, it has low toxicity and good environmental acceptability, is cheap and plentiful. There are many reports on photovoltaic devices using cuprous oxide $\left(\mathrm{Cu}_{2} \mathrm{O}\right)$ as the active layer ${ }^{1-8}$ because the theoretical energy conversion efficiency of a $\mathrm{Cu}_{2} \mathrm{O}$ solar cell is about $20 \%$. ${ }^{1} \mathrm{Cu}_{2} \mathrm{O}$-based solar cells have been fabricated by various techniques. Sears et al. ${ }^{2}$ and Mittiga et al. ${ }^{3}$ fabricated the $\mathrm{Cu}_{2} \mathrm{O}$ solar cell by oxidizing copper at high temperature. To deposit $\mathrm{ZnO}-\mathrm{Cu}_{2} \mathrm{O}$ heterojunctions, Minami et $\mathrm{al}^{4}$ fabricated $\mathrm{ZnO}$ by $\mathrm{RF}$ magnetron sputtering or pulsed laser deposition on the $\mathrm{Cu}_{2} \mathrm{O}$ sheet. Also, $\mathrm{ZnO} / \mathrm{Cu}_{2} \mathrm{O}$ heterojunctions have been fabricated using RF-magnetron sputtering by Ishizuka et al. ${ }^{5}$ Some researchers have fabricated heterojunctions based on $\mathrm{ZnO}$ and $\mathrm{Cu}_{2} \mathrm{O}$ obtained by electrochemical deposition (ECD) ${ }^{6-8}$ In the previous paper, we reported that the $\mathrm{Cu}_{\mathrm{x}} \mathrm{O}$ films exhibit p-type conduction and photosensitivity and hence will be suited for heterojunction solar cells. ${ }^{9}$ In the present work, to fabricate the $\mathrm{ZnO}-\mathrm{Cu}_{2} \mathrm{O}$ heterojunction, $\mathrm{Cu}_{2} \mathrm{O}$ layers are deposited by the chemical bath deposition (CBD) technique using aqueous solutions containing $\mathrm{CuSO}_{4}$ and $\mathrm{Na}_{2} \mathrm{SO}_{3}{ }^{9}$. The counterpart of the heterojunction, i.e., a $\mathrm{ZnO}$ layer is deposited by ECD. There are several reports on $\mathrm{CBD}$ of $\mathrm{Cu}_{2} \mathrm{O},{ }^{10,11}$ but to the best of our knowledge, a heterojunction based on $\mathrm{CBD} \mathrm{Cu}_{2} \mathrm{O}$ has never been reported.

\section{EXPERIMENTAL PROCEDURE}

To fabricate $\mathrm{ZnO}-\mathrm{Cu}_{2} \mathrm{O}$ heterojunctions, $\mathrm{Cu}_{2} \mathrm{O}$ was deposited by $\mathrm{CBD}$ and $\mathrm{ZnO}$ by ECD. The substrate was indium-tin-oxide (ITO) coated glass sheet. On the surface of the top layer, an indium electrode $(1 \times 1 \mathrm{~mm}$ size) was deposited by vacuum coating unit. Both the substrate structure $\mathrm{In} / \mathrm{ZnO} / \mathrm{Cu}_{2} \mathrm{O} / \mathrm{ITO}$ and the superstrate structure $\mathrm{In} / \mathrm{Cu}_{2} \mathrm{O} / \mathrm{ZnO} / \mathrm{ITO}$ were fabricated.

To deposit $\mathrm{Cu}_{2} \mathrm{O}$ thin films, $\mathrm{CuSO}_{4}(20 \mathrm{mmol} / \mathrm{L})$ and $\mathrm{Na}_{2} \mathrm{SO}_{3}(100 \mathrm{mmol} / \mathrm{L})$ were used as a chemical reagent with deionized water. The solution $\mathrm{pH}$ was about 7.2 as unadjusted. The amount of the solution was $50 \mathrm{~mL}$. $\mathrm{CuSO}_{4}$ was first dissolved in the water, and then $\mathrm{Na}_{2} \mathrm{SO}_{3}$ was added. The solution was stirred for $30 \mathrm{~min}$ before deposition. The solution was almost colorless after the stirring. The solution container was put on a heater plate heated to $200{ }^{\circ} \mathrm{C}$, and the solution temperature was increased to a steady-state temperature of $80{ }^{\circ} \mathrm{C}$. The deposition time (time after the container was put on the heater plate) was $30 \mathrm{~min}$. After the deposition experiments, the deposited films were washed softy in pure water and dried naturally in air. To modify the surface morphology, ethylendiamine (EDA) was added to the above working solution. EDA is one of the chemicals commonly used as a complexing agent for metal ions. $0.03 \mathrm{~mL}$ or $0.06 \mathrm{~mL}$ of EDA was added in the solution just after the stirring. The solution color was light indigo after adding the EDA and it became deep indigo during heating. The deposition time of these samples were $60 \mathrm{~min}$. $\mathrm{ZnO}-\mathrm{Cu}_{2} \mathrm{O}$ heterojunctions were fabricated with and without EDA addition.

To deposit $\mathrm{ZnO}$ layers, a solution containing 100 $\mathrm{mmol} / \mathrm{L}$ of $\mathrm{Zn}\left(\mathrm{NO}_{3}\right)_{2}$ was used. A three-electrode cell was used with a saturated calomel electrode (SCE) as the reference electrode. $\mathrm{pH}$ was not controlled ( 4), deposition voltage (DC) was $-1.3 \mathrm{~V}$, deposition temperature was $60^{\circ} \mathrm{C}$, and deposition time was $30 \mathrm{~s}-10$ $\min$.

An Accretech Surfcom-1400D profile meter was used for measuring the thickness of the films and the heterojunctions. For compositional analysis, Auger electron spectroscopy (AES) measurement was carried out for the $\mathrm{Cu}_{2} \mathrm{O}$ films using a JEOL JAMP 7800 at a probe voltage of $10 \mathrm{kV}$ and a current of $2 \times 10^{-8} \mathrm{~A}$. Argon ion etching with an acceleration voltage of $3 \mathrm{kV}$ and a current of $8 \mathrm{~mA}$ was used to sputter the film surface. 
The $\mathrm{Cu} / \mathrm{O}$ atomic ratios were calculated using standard $\mathrm{CuO}$. The X-ray diffraction (XRD) measurement was carried out for the $\mathrm{Cu}_{2} \mathrm{O}$ films by the RIGAKU RINT-2000 diffractometer using $\mathrm{CuK} \alpha_{1}$ radiation. The surface morphology of the $\mathrm{Cu}_{2} \mathrm{O}$ film was analyzed using a Hitachi S-2000S scanning electron microscope (SEM) at a constant acceleration voltage of $10 \mathrm{kV}$ and a magnification of 2000. To determine the type of conduction and to estimate the photosensitivity of the $\mathrm{Cu}_{2} \mathrm{O}$ films, photo electrochemical (PEC) measurements were carried out using the three-electrode cell with the SCE reference electrode. The solution contained 100 $\mathrm{mmol} / \mathrm{L} \mathrm{Na}_{2} \mathrm{SO}_{3}$. The incident light from a xenon lamp (about $100 \mathrm{~mW} / \mathrm{cm}^{2}$ ) was irradiated on the backside of the sample and turned off and on mechanically every $5 \mathrm{~s}$. The current was measured under application of a ramp voltage with a scan rate of $5 \mathrm{mV} / \mathrm{s}$, first in the anodic bias range $(0$ to $+1 \mathrm{~V})$ and then in the cathodic bias range $(0$ to $-1 \mathrm{~V})$. The photovoltaic properties of the heterojunctions were measured under AM1.5 solar illumination with a power of $100 \mathrm{~mW} / \mathrm{cm}^{2}$.

\section{RESULTS AND DISCUSSION}

3.1 $\mathrm{Cu}_{2} \mathrm{O}$ thin films

The chemical reactions of the $\mathrm{Cu}_{2} \mathrm{O}$ thin film deposition were completed within 30 minutes without EDA. Thickness of this deposition time depends on the solution amount for a particular solution concentration ${ }^{9}$. The film thickness was around $3 \mu \mathrm{m}$ for deposition without EDA, $1.2 \mu \mathrm{m}$ for deposition with $0.03 \mathrm{~mL}$ EDA, and $0.5 \mu \mathrm{m}$ for deposition with $0.06 \mathrm{~mL}$ EDA.

The AES results show that only copper and oxygen elements are present in the $\mathrm{Cu}_{2} \mathrm{O}$ samples (Fig.1). The near-surface region is more oxygen-rich than the bulk.

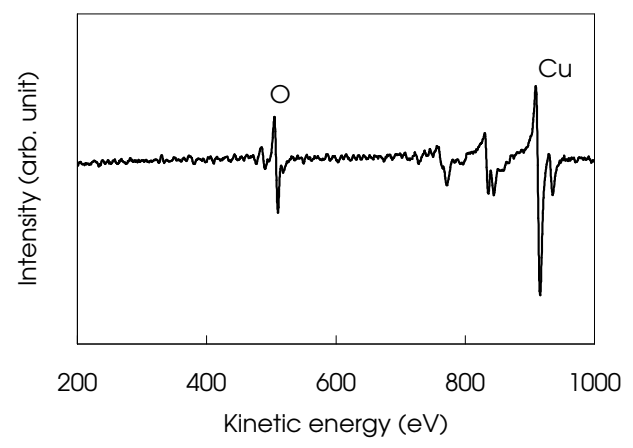

Fig. 1. AES spectrum of the film deposited with 0.03 mL EDA.

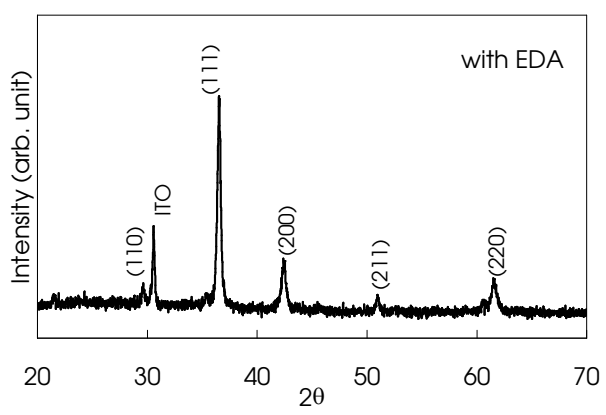

Fig. 2. XRD pattern of the film deposited with $0.03 \mathrm{~mL}$ EDA
The film composition was evaluated from the AES spectra recorded after 10 min sputtering of the surface. For the film deposited without EDA, the $\mathrm{Cu} / \mathrm{O}$ ratio calculated is 1.8 , while it is about 2 for the films deposited with EDA. Thus $\mathrm{Cu} / \mathrm{O}$ ratio approached to the stoichiometiric composition by addition of EDA.

Figure 2 shows the XRD spectrum for the film deposited with EDA. There is no significant difference in either peak position or width between the samples deposited with and without EDA. A peak due to ITO was observed near $2 \theta=31^{\circ}$, and all other dominant peaks are attributed to $\mathrm{Cu}_{2} \mathrm{O}$ according to the ICSD standard data. Thus the XRD results show that the films are dominantly cubic crystalline $\mathrm{Cu}_{2} \mathrm{O}$ with a lattice parameter $4.25 \AA$. For the film deposited without EDA,

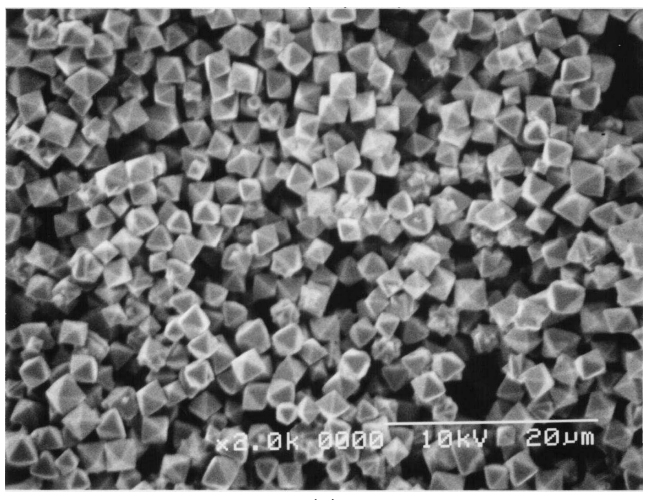

(a)

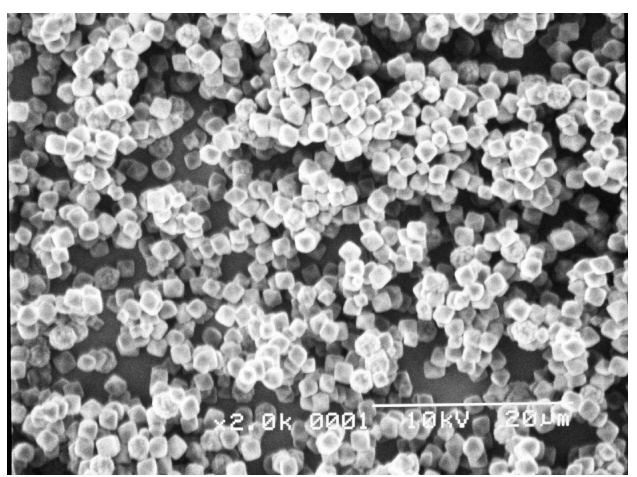

(b)

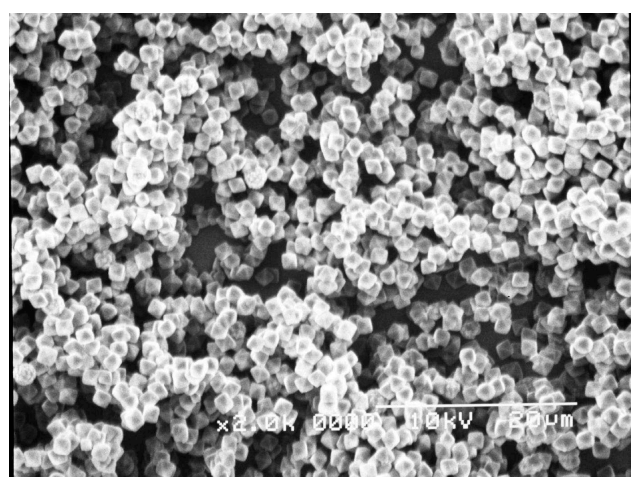

(c)

Fig. 3. SEM photographs of the films deposited (a) without EDA, (b) with $0.03 \mathrm{~mL}$ EDA and (c) with 0.06 mL EDA. 
the AES results showed the $\mathrm{Cu} / \mathrm{O}$ ratio $\sim 1.8$, but the observed XRD peaks are all attributed to $\mathrm{Cu}_{2} \mathrm{O}$. It has been widely believed that in copper oxide, excess oxygen ions (or copper ion vacancies) are the main sources of acceptors, which produce p-type conductivity. ${ }^{12,13}$ Our samples are p-type, and thus those $\mathrm{Cu}$-deficiency defects are present in a large number in the crystalline phase of $\mathrm{Cu}_{2} \mathrm{O}$.

Figure 3 (a) shows the SEM photographs of the films deposited (a) without EDA, (b) with $0.03 \mathrm{~mL}$ EDA, and (c) with $0.06 \mathrm{~mL}$. The film deposited without EDA consists of octahedral particles, and a similar particle shape was also observed in the previous chemical synthesis works. ${ }^{14,15}$ Figures 3(b) and (c) show SEM photographs for the films deposited with $0.03 \mathrm{~mL}$ and $0.06 \mathrm{~mL}$ of EDA, respectively. The morphology reveals the same properties as that of the films deposited without EDA, but the particles size is smaller. This would be because EDA stabilized the copper ions, reduced the reaction rate, and prevented the particles from growing to bigger size. We attempted to measure the band gap by the optical transmission measurement for the films deposited with and without EDA, but the transmission was low, less than $10 \%$, and a clear absorption edge was not observed. This will be because the light was scattered by the rough surface structure, revealed by the SEM photographs.

Figure 4 shows the PEC measurement results for the films deposited without and with $0.03 \mathrm{~mL}$ EDA. It is clear that the current was changed due to the light chopping, and thus the films show good photosensitive behaviors. Under illumination, some carriers were excited in the illuminated region of the film. Then excited minority carriers diffused to the surface during their lifetime to participate in the electrochemical reaction at the electrolyte interface. For our thin films, the photocurrent is negative, and its magnitude is larger under cathodic biasing than under anodic biasing. This implies that the minority carriers generated here are electrons. Thus, the deposited films are p-type semiconductors. Figure 4 shows that the photocurrent is slightly larger for the film deposited with EDA.

\section{2 $\mathrm{ZnO}-\mathrm{Cu}_{2} \mathrm{O}$ heterojunctions}

Before fabricating the heterostructure, we deposited $\mathrm{Cu}_{2} \mathrm{O}$ and $\mathrm{ZnO}$ layers separately on ITO and confirmed that the interface with ITO has the ohmic character for both $\mathrm{Cu}_{2} \mathrm{O}$ and $\mathrm{ZnO}$. Figure 5 shows the I-V characteristics of the heterojunctions, for which the $\mathrm{Cu}_{2} \mathrm{O}$ layers were deposited without EDA. The sample structure is the substrate structure for Fig. 5(a) and the superstrate structure for Fig. 5(b). The $\mathrm{ZnO}$ layer thickness is about $0.2 \mu \mathrm{m}$ for deposition time of $30 \mathrm{~s}$, about $1 \mu \mathrm{m}$ for deposition time of $2.5 \mathrm{~min}$ and about 2 $\mu \mathrm{m}$ for deposition time of $10 \mathrm{~min}$. In the substrate structure, the heterojunction of the shorter $\mathrm{ZnO}$ deposition time showed better rectification. On the other hand, better rectification appeared for the superstrate structure for which the $\mathrm{ZnO}$ deposition time was longer. However, photovoltaic properties have not been observed for those samples deposited without EDA.

Figure 6 shows I-V characteristics of the superstrate heterostructures with $\mathrm{Cu}_{2} \mathrm{O}$ films deposited with (a) 0.03 $\mathrm{mL}$ EDA and (b) $0.06 \mathrm{~mL}$ EDA. The $\mathrm{ZnO}$ deposition

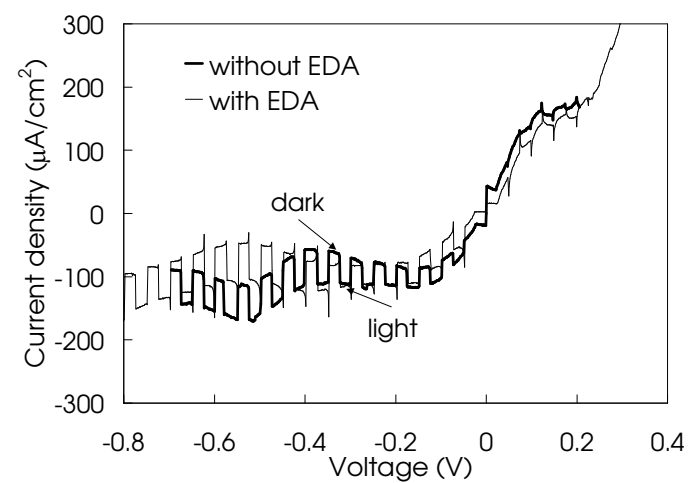

Fig. 4. PEC measurement results for the $\mathrm{Cu}_{2} \mathrm{O}$ films deposited without and with $0.03 \mathrm{~mL}$ EDA.

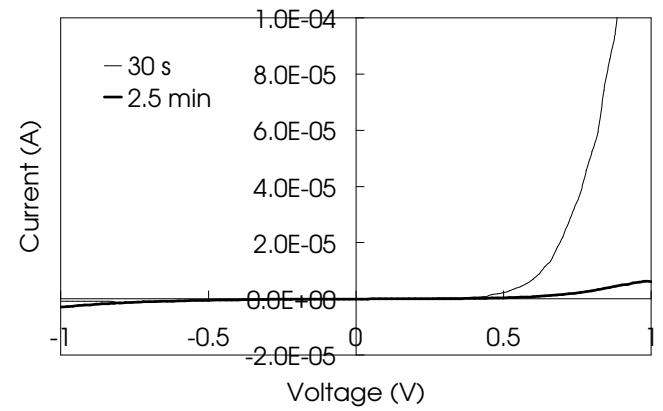

(a)

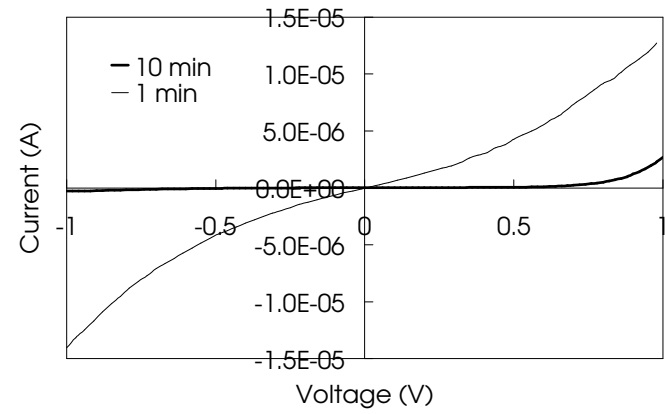

(b)

Fig. 5. I-V characteristics for (a) the substrate and (b) superstrate structure heterojunctions with two different $\mathrm{ZnO}$ deposition times. $\mathrm{Cu}_{2} \mathrm{O}$ was deposited without EDA.

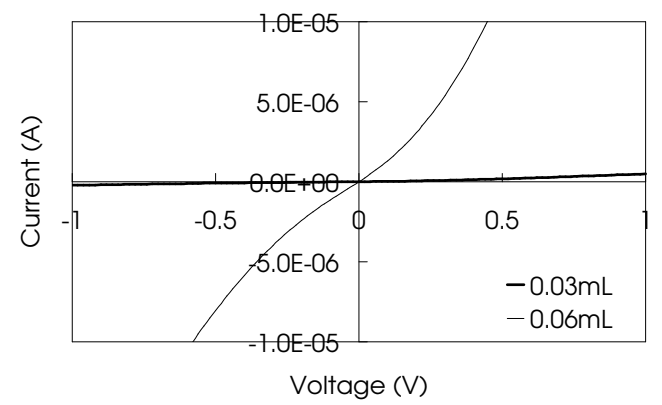

Fig. 6. I-V characteristics for the superstrate structure heterojunctions with $\mathrm{Cu}_{2} \mathrm{O}$ deposited with $0.03 \mathrm{~mL}$ EDA and $0.06 \mathrm{~mL}$ EDA. 
time is $2.5 \mathrm{~min}$. The rectification properties are not good, but weak photovoltaic effects appeared for these samples. Figures 7(a) and 7(b) show I-V characteristics with and without AM1.5 illumination for the superstrate structure with $\mathrm{Cu}_{2} \mathrm{O}$ layers deposited using (a) $0.03 \mathrm{~mL}$ and (b) $0.06 \mathrm{~mL}$ of EDA. For the samples deposited with EDA, the particle size is smaller and adhesion is better than for the films deposited without EDA. Surface roughness and porous nature will be the main cause for absence of the photovoltaic effects for the samples deposited without EDA. We also fabricated the substrate structure based on the films deposited with EDA, but photovoltaic effects were not observed.

Although the photovoltaic effects were observed for the samples deposited with EDA, the efficiency is still very low, $0.002 \%$ with $\mathrm{V}_{\mathrm{oc}}=0.1 \mathrm{~V}, \mathrm{I}_{\mathrm{sc}}=0.07 \mathrm{~mA} / \mathrm{cm}^{2}$ and F.F. $=0.27$ for Fig.7(a) and $0.0007 \%$ with $\mathrm{V}_{\mathrm{oc}}=0.014 \mathrm{~V}$, $\mathrm{I}_{\mathrm{sc}}=0.19 \mathrm{~mA} / \mathrm{cm}^{2}$ and F.F. $=0.25$ for Fig. 7(b). To improve further, a more compact and dense $\mathrm{Cu}_{2} \mathrm{O}$ film needs to be fabricated by, for example, using other additives to the solution.

\section{CONCLUSIONS}

The $\mathrm{Cu}_{2} \mathrm{O}$ layers have been deposited by $\mathrm{CBD}$ using aqueous solutions containing $\mathrm{CuSO}_{4}$ and $\mathrm{Na}_{2} \mathrm{SO}_{3}$ without and with adding small amount of EDA. The $\mathrm{Cu}_{2} \mathrm{O}$ films are crystalline with a cubic crystal structure, have $\mathrm{Cu} / \mathrm{O}$ ratios of $1.7-2$, and consist of octahedral particles, whose size is reduced by addition of EDA. To fabricate pn heterojunctions, $\mathrm{ZnO}$ layers have been deposited by electrochemical deposition. Rectification properties and week photovoltaic effects are observed for the heterojunctions fabricated using the solution with EDA. Our technique is a very low-cost technique, using those inexpensive source chemicals and the simple apparatus. Therefore our CBD technique is potentially suitable for commercial production of solar cells.

\section{ACKNOWLEDGEMENT}

We would like to thank Dr. M. Kato for his helpful discussion.

\section{REFERENCES}

[1] A. E. Rakhshani, Solid-State Electronics, 29, 7-17 (1986).

[2] W. M. Sears, E. Fortin and J. B. Webb, Thin Solid Films, 103, 303-309 (1983).

[3] A. Mittiga, E. Salza, F. Sarto, M. Tucci, and R. Vasanthi, Appl. Phys. Lett.,. 88, 163502 (2006).

[4] T. Minami, H. Tanaka, T. Shimakawa, T. Miyata and H. Sato, Jpn. J. Appl. Phys., 43, L917-L919 (2004).

[5] S. Ishizuka, K. Suzuki, Y. Okamoto, M. Yanagita, T. Sakurai, K. Akimoto, N. Fujiwara, H. Kobayashi, K. Matsubara and S. Niki, Phys. Stat. Sol., (c) 1, 1067-1070

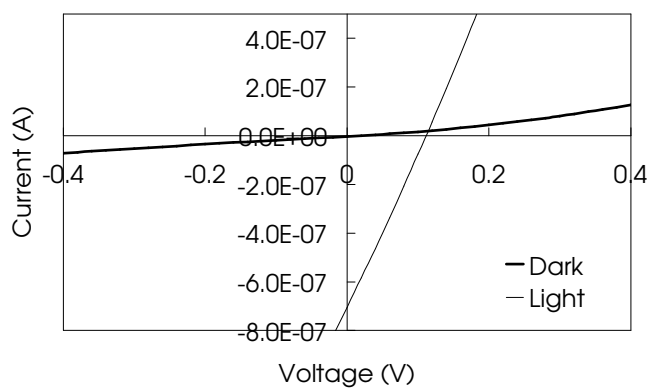

(a)

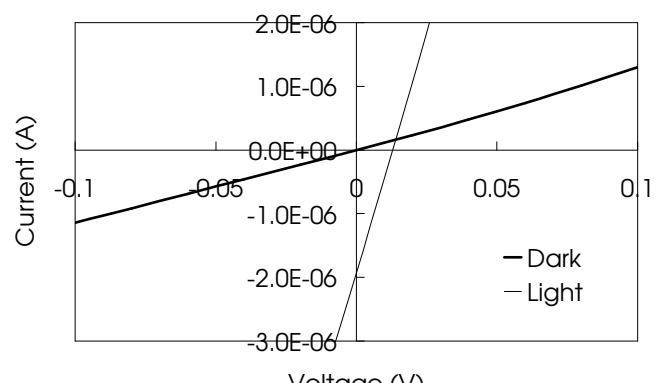

(b)

Fig. 7. Photovoltaic properties for the $\mathrm{Cu}_{2} \mathrm{O} / \mathrm{ZnO}$ (superstrate structure) heterojunctions for which $\mathrm{Cu}_{2} \mathrm{O}$ was deposited with (a) $0.03 \mathrm{~mL}$ EDA and (b) $0.06 \mathrm{~mL}$ EDA.

(2004).

[6] J. Katayama, K. Ito, M. Matsuoka and J. Tamaki, J. Appl. Electrochem., 34, 687-692 (2004).

[7] S. S. Jeong, A. Mittiga, E. Salza, A. Masci and S. Passerini, Electrochimica Acta, 53, 2226-2231 (2008).

[8] M. Izaki, T. Shinagawa, K. Mizuno, Y. Ida, M. Inaba, and A. Tasaka, J. Phys. D: Appl. Phys., 40, 3326-3329. (2007)

[9] M. Muhibbullah and M. Ichirura, Jpn. J. Appl. Phys., 49, 081102 (2010).

[10] M. Ristov, G. I. Sinadinovski, and I. Grozdanov, Thin Solid Films 123, 63-67 (1985) 63.

[11] M. T. S. Nair, L. Guerrero, O. L. Arenas, and P. K. Nair, Appl. Surf. Sci. 150 143-151 (1999).

[12] V.F. Drobny and D.L. Pulfrey, Thin Solid Films, 61, 89-98 (1979).

[13] W. Siripala and K. Premasiri Kumar, Semicond. Sci. Technol., 4, 465-468 (1989).

[14] F. Du, J. Liu and Z. Guo, Mater. Res. Bull., 44, 25-29 (2009).

[15] C. Lu, L. Qi, J. Yang, X. Wang, D. Zhang, J. Xie and J. Ma, Advanced Mater., 17, 2562-2567 (2005).

(Received Janurary 28, 2011; Accepted March 14, 2011) 